\title{
Eat and Die: The Last Meal of Sacrificed Chimú Camelids at Huanchaquito-Las Llamas, Peru, as Revealed by Starch Grain Analysis
}

\author{
Clarissa Cagnato (D), Nicolas Goepfert, Michelle Elliott, Gabriel Prieto, John Verano, and Elise Dufour
}

\begin{abstract}
This article reconstructs the final diet of sacrificed domestic camelids from Huanchaquito-Las Llamas to understand whether feeding was part of the ritual practice. The site is situated on the northern coast of Peru and is dated to the fifteenth century AD (Late Intermediate period; LIP). It was used by the Chimús to kill and bury a large number of camelids, mostly juveniles. We reconstructed the final meal of 11 of the sacrificed individuals by analyzing starch grains derived from the associated gut contents and feces. The starch grains were well preserved and allowed for the determination of five plant taxa. The comparison with previously published and new stable isotope analyses, which provide insights into long-term diet, indicates that the Chimús managed their herds by providing maize as fodder and allowing them to graze on natural pasture; yet they reserved special treatment for sacrificial animals, probably bringing them together a few hours or days before the sacrificial act. We show for the first time the consumption of unusual food products, which included manioc, chili peppers, and beans, as well as cooked foods. Our study provides unique information on Chimú camelid ritual and herding practices.
\end{abstract}

Keywords: ritual diet, archaeobotany, stable isotope analysis, Late Intermediate period

El presente artículo aborda la reconstrucción de la dieta ingerida por camélidos domesticados antes de ser sacrificados y enterrados en el sitio arqueológico Huanchaquito-Las Llamas, situado en la costa norte de Perú y data del siglo XV de nuestra era (periodo Intermedio Tardio). Este sitio fue utilizado por los Chimús para matar y enterrar una gran cantidad de camélidos, en su mayoría juveniles. La identificación de la dieta ingerida por 11 de los camélidos antes de ser sacrificados, se realizó a través del estudio de los granos de almidón obtenidos del contenido intestinal y heces asociadas. El buen estado de conservación de los granos de almidón permitió la determinación de cinco taxones de plantas. La comparación con los análisis de isótopos estables publicados anteriormente, así como los nuevos proporcionaron información respecto a la dieta de los camélidos a largo plazo, determinando que los Chimús alimentaron sus rebaños con maíz como forraje y los dejaron pastar en espacios naturales. Además de recibir un tratamiento especial, es probable que estos camélidos hayan sido congregados unas pocas horas o días antes de ser sacrificados. Este estudio ha identificado por primera vez el consumo de alimentos inusuales ingeridos por camélidos, tales como mandioca, chiles y frijoles, así como alimentos cocinados. Nuestro estudio proporciona información inédita respecto al ritual de camélidos Chimú y las prácticas de pastoreo.

Palabras claves: dieta ritual, arqueobotánica, isótopos estables, periodo Intermedio Tardío

$\mathrm{R}$ itual killings or sacrifices were an important component of the cultural life of various prehispanic populations in

the Andean region, with both human and domestic animal sacrifices being practiced (Goepfert 2012; Klaus and Toyne 2016; Verano 1995,

Clarissa Cagnato (ccagnato@ wustl.edu, corresponding author) and Nicolas Goepfert $\square$ UMR 8096 Archéologie des Amériques (CNRS-Université Paris 1 Panthéon-Sorbonne), 9 rue Mahler, 75004 Paris, France

Michelle Elliott — UMR 7041 Archéologie et Sciences de l'Antiquité, University Paris 1 Panthéon-Sorbonne, MSH Mondes, Nanterre, F-92023, France

Gabriel Prieto $\mathbf{a}$ Department of Anthropology, University of Florida, Gainesville, Florida 32603, USA

John Verano $\square$ Department of Anthropology, Tulane University, 101 Dinwiddie Hall, 6823 St. Charles Ave., New Orleans, Louisiana 70118, USA

Elise Dufour — UMR 7209, Archéozoologie, Archéobotanique, Sociétés, Pratiques, Environnements, Muséum national d'Histoire naturelle, CNRS, CP 55 rue Cuvier, 75005 Paris, France

Latin American Antiquity 32(3), 2021, pp. 595-611

Copyright (C) The Author(s), 2021. Published by Cambridge University Press on behalf of the Society for American Archaeology. This is an Open Access article, distributed under the terms of the Creative Commons Attribution licence (http://creativecommons.org/licenses/by/4.0/), which permits unrestricted re-use, distribution, and reproduction in any medium, provided the original work is properly cited.

doi:10.1017/laq.2021.19 


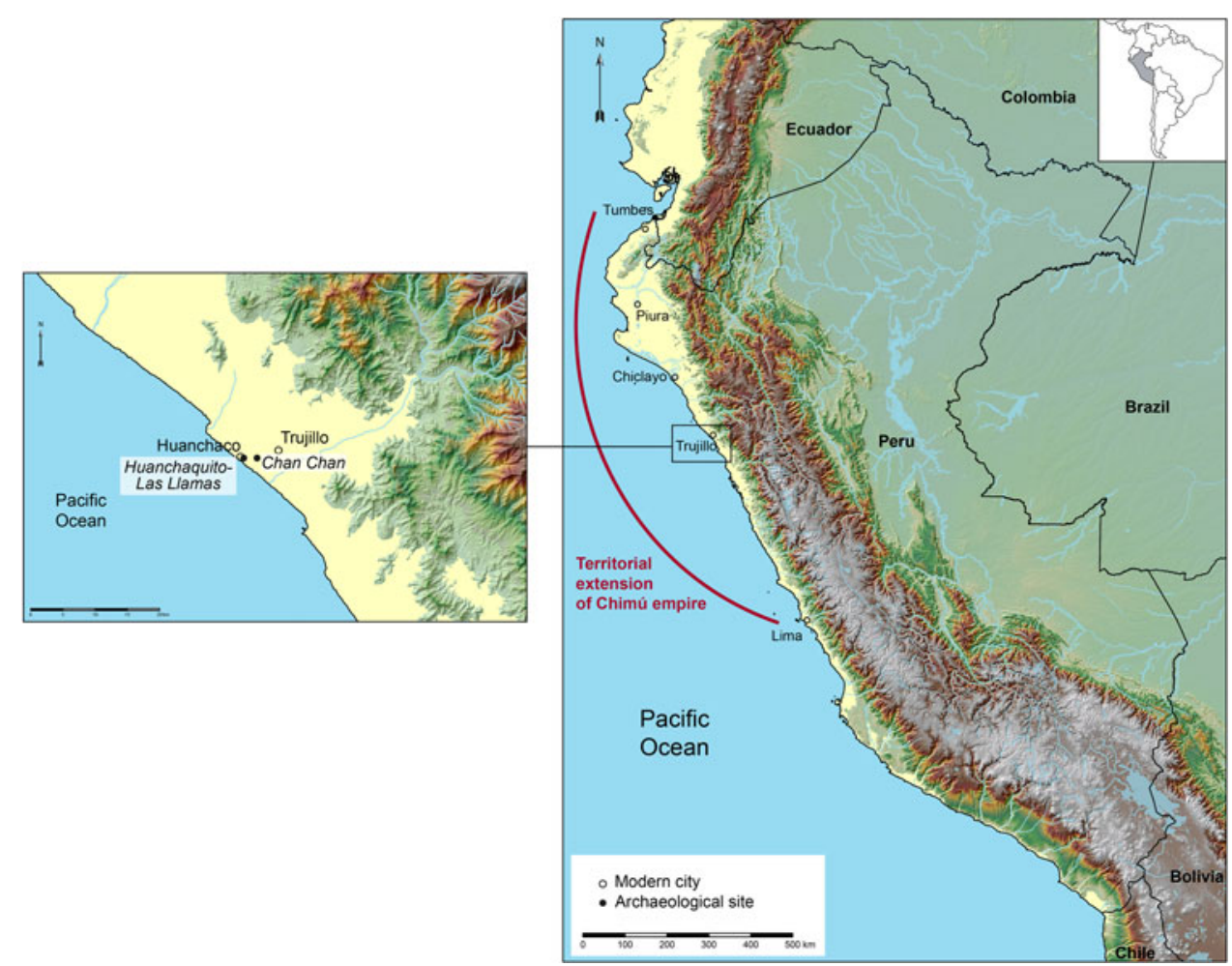

Figure 1. Location of Huanchaquito-Las Llamas (map by Jean-François Cuénot and Nicolas Goepfert). (Color online)

2001). Domestic camelids, namely llamas (Lama glama) and alpacas (Vicugna pacos), were the principal animals involved in such practices (Goepfert 2011, 2012; Wheeler et al. 1995). The sacrifices could have fulfilled several functions and taken various forms (Goepfert 2012). However, all the sacrificed animals were part of a supernatural gift economy in a highly ritualized context, involving a set of complex relations between the living and the spirits and ancestors (Flores Ochoa et al. 1994; Szpak et al. 2016). Recent studies have explored the life history of the sacrificed individuals, in particular their geographical origin (Andrushko et al. 2011; Tung and Knudson 2010) and the special treatments they received. For example, the children sacrificed by the Inca in a practice known as capacocha had a special diet in the months preceding their death. Notably, the Llullaillaco children discovered in Argentina seem to have ingested alcohol and coca in the months before their death (Wilson et al. 2013). This raises the question whether a special final meal was also given to these camelids before they were sacrificed.
This article aims to understand the final diet of the sacrificed domestic camelids from the Huanchaquito-Las Llamas (HLL) site, which is located on the northern coast of Peru (Figure 1). HLL, dated to the fifteenth century $\mathrm{AD}$ in the Late Intermediate period (LIP), is thus far a unique example of such a context because of the exceptional preservation of the animal corpses due to the arid climatic conditions that prevail on the Pacific coast (Goepfert and Prieto 2016; Goepfert et al. 2020; Prieto et al. 2019). Although the exact reasons for this mass killing are unknown, one motivation could be linked to a sudden climatic event (Prieto et al. 2017, 2019). Various studies have already been done on some of these animal corpses. The paleoparasitological analysis of gut contents and feces by Le Bailly and colleagues (2020) described the internal parasites and aimed to determine the health status of the animals. Zooarchaeological and stable isotopic analysis (SIA) have revealed some of the criteria used for animal selection (Dufour et al. 2020). Only young animals were chosen, and 
most had a brown coat, although some were completely beige (Goepfert et al. 2020; Prieto et al. 2019). The relationship between the stable isotopic composition of an animal and that of its diet and environment allows the reconstruction of an animal's life history (e.g., DeNiro and Epstein 1978; Schoeninger and DeNiro 1984; Zazzo et al. 2010). This approach has been used in the Andean region to study camelid herding and management strategies (e.g., Dufour et al. 2014; Samec et al. 2018; Szpak et al. 2014) and has suggested that the HLL camelid offerings were from several different herds, raised in the Lowlands. It does not support the existence of specific herds dedicated to ritual purposes (Dufour et al. 2020).

The SIA of bone collagen represents the weighted average of dietary intake. Over their lives, the HLL camelids consumed diverse wild and cultivated plants in variable proportions, depending on the herders' practices and choices (Dufour et al. 2020). Diet variability was large, but in all cases, the proportion of $\mathrm{C}_{4}$ plantsplants with a photosynthesis pathway that minimizes photorespiration and that are thus adapted to arid conditions and are mostly present in tropical regions-was moderate to large compared with that of $\mathrm{C}_{3}$ plants. However, SIA can only point to the exploitation of a habitat type, such as lomas (areas of fog-watered vegetation), or quantify the consumption of food categories such as plants using $\mathrm{C}_{3}$ and $\mathrm{C}_{4}$ photosynthesis pathways; thus, it can only be suggestive of specific plant species. Maize (Zea mays), the principal cultivated $\mathrm{C}_{4}$ plant, is thought to represent a significant dietary input and could explain the very high $\mathrm{C}_{4}$ plant isotopic signature of some of the individuals. However, grama salada (Distichlis spicata), a wild, salt-tolerant $\mathrm{C}_{4}$ grass, could have also constituted a sustainable grazing resource because it is widespread. Given that the SIA of bone collagen represents a dietary average over a long period of time, it cannot track short-term dietary changes. Ethnographic data may be a good source of information about short-term changes in diet before sacrifice, but none are available in this case. Therefore, to address whether a special (perhaps ritually significant) meal was given to the camelids before their sacrifice, we studied starch grains, derived principally from the associated gut contents of the sacrificed camelids.

\section{Starch Grain Analysis}

Starch grains are the energy-storage units of plants. Composed of two different glucose chains, they are tiny particles, ranging in size from 1 to $100 \mu \mathrm{m}$. They are stored in various organs in a green plant; however, dense amounts of starch are often concentrated in seeds, tubers, and fruits (Haslam 2004). In archaeology, starch has been successfully extracted from tools and ceramic vessels (Cagnato and Ponce 2017), organic containers (Duncan et al. 2009), dental calculus (Piperno and Dillehay 2008), coprolites (Vinton et al. 2009), and sediments (Therin et al. 1999). The presence of starch has played an important role in tropical areas, where macrobotanical remains may not be preserved as often or as well as they are in other parts of the world (Dickau et al. 2007). The long-term survival of starch grains makes them especially useful for better identifying plant parts that do not preserve well and are thus underrepresented in the macrobotanical archive, including underground storage organs (i.e., tubers and rhizomes; Piperno and Holst 1998). These elements are useful because they tend to be ubiquitous in plants, they have a series of morphological features that often allow them to be identified to the taxon (genus or even species) level, and their size and shape can be highly diagnostic (Gott et al. 2006). The recovery, and identification, of starch grains in different archaeological contexts in South America, and more particularly in the Andean region, is not novel (see Duncan et al. 2009; Ikehara et al. 2013; Piperno and Dillehay 2008; Vinton et al. 2009). Although microbotanical research has been carried out on camelid feces remains from Peru and Argentina (see Bonavia 2008a; Caruso Fermé et al. 2018; Jones 1990; Jones and Bonavia 1992; Korstanje 2005; Mosca Torres et al. 2018), only one study revealed the presence of starch grains, belonging to Typha sp. (Bonavia 2008a:403). Our study is unique because, through the recovery and identification of starch grains in gut remains, it identified multiple species and thus provides some insights into the final diet of these camelids 


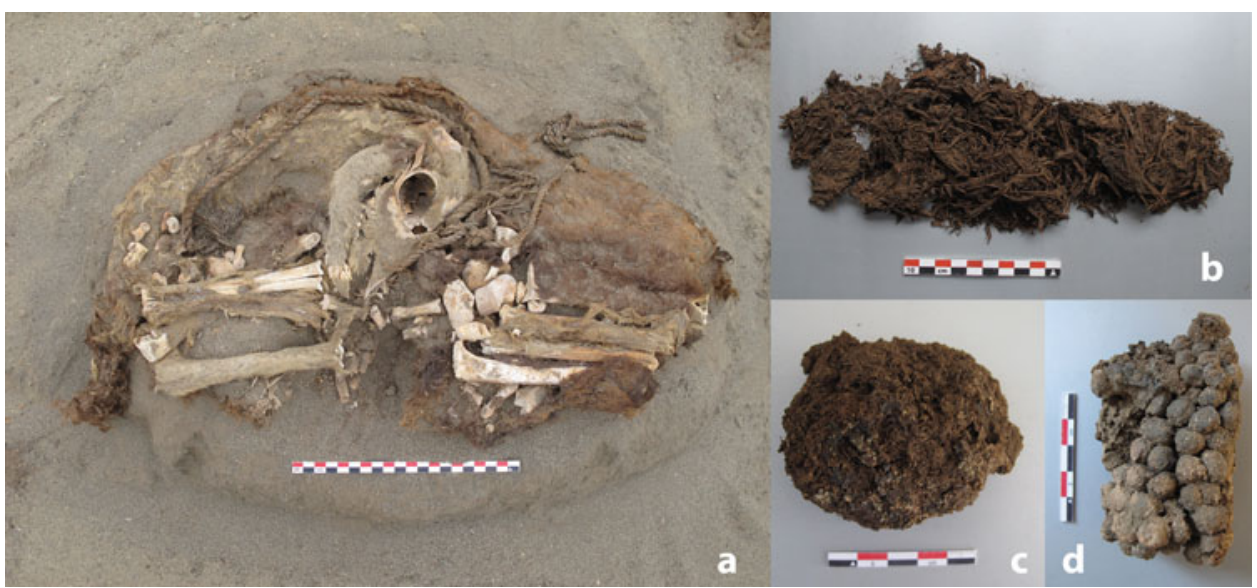

Figure 2. Camelid, gut, and feces remains from Huanchaquito-Las Llamas: (a) camelid (CA-07); (b, c) gut contents at different levels of digestion (CA-20 and CA-47); and (d) feces (CA-05). Photos by Nicolas Goepfert. (Color online)

before their sacrifice. We compare the short-term dietary history as recorded by starch grain results with the long-term dietary history as recorded by SIA to distinguish between the regular and the special diet of these camelids.

\section{Materials and Methods}

The site of Huanchaquito-Las Llamas is located in the Moche Valley, on a dune $300 \mathrm{~m}$ from the shoreline. It is $1.5 \mathrm{~km}$ northwest of Chan Chan, the ancient Chimú capital, and $4 \mathrm{~km}$ from the modern city of Trujillo, in the La Libertad region. It yielded 206 sacrificed domestic camelid individuals, probably llamas, and 140 human individuals, of whom 137 were children and 3 were adults (Prieto et al. 2019). The camelids were, for the most part, in a good state of preservation, with their fleece still present (Figure 2a), their natural mummification made possible by the dry conditions of the Peruvian coast (Collin Delavaud 1984). For some of the individuals, their gut contents (Figure 2b, c), feces (Figure 2d), and ropes used to handle them were also still present. The sacrificial event has been radiocarbon dated to between AD 1400 and 1450 (Prieto et al. 2019). At that time, the Chimú empire was at its apogee, having reached its maximum territorial extension-from northern Peru (the area bordering Ecuador) to the central coast (modern-day Lima). Major sites controlled this vast territory, which extended $1,000 \mathrm{~km}$ north to south, administering local populations and their intensive agriculture (Moore and Mackey 2008).

We collected gut contents and feces from 52 individuals in the field over the course of three excavation seasons (2011, 2014, and 2016). The samples were exported with the permission of the Ministerio de Cultura of Peru $\left(\mathrm{N}^{\circ} 050\right.$ 2016-VMPCIC-MC). We carried out starch grain analysis on the gut contents of 11 camelids, ranging from 6 months to 1.5 years in age (based on observations of tooth eruption and tooth wear; Table 1, Figure 2b, c), and on the feces of one of these individuals (CA-05). This corpus represents $21 \%$ of the available gut and fecal samples. The other $79 \%$ of the samples had already been used for paleoparasitological (Le Bailly et al. 2020) and phytolith analysis (in an ongoing study), both of which rendered them unusable for subsequent starch grain analysis.

The samples were treated at the MSH Mondes following previously outlined laboratory extraction methods (Cagnato and Ponce 2017). Before analysis, all the laboratory consumables were sterilized using bleach. We concentrated $1 \mathrm{~g}$ of the gut remains from each sample by centrifugation. To dissolve any limescale in the sample, we added $10 \mathrm{ml}$ of $0.1 \%$ ethylenediaminetetraacetic acid (EDTA) and then rinsed it with distilled water. We then added hydrogen peroxide $(5.75 \%)$ to ensure that nonstarch organics would be destroyed and to aid in breaking up the sediment. We performed heavy-liquid flotation using sodium polytungstate (SPT), which 
Table 1. Starch Grain Results Obtained from HLL Camelid Gut Contents and Feces.

\begin{tabular}{|c|c|c|c|c|c|c|c|c|c|}
\hline Camelid \# & Age & Coat Color & $\begin{array}{c}\text { Maize } \\
\text { (Zea mays) }\end{array}$ & $\begin{array}{l}\text { Lenticular } \\
\text { Grains }^{\mathrm{a}}\end{array}$ & $\begin{array}{l}\text { Fabaceae } \\
\text { Family }\end{array}$ & $\begin{array}{c}\text { Manioc } \\
\text { (Manihot } \\
\text { esculenta) }\end{array}$ & $\begin{array}{c}\text { Algorrobo } \\
\text { (Prosopis sp.) }\end{array}$ & Unidentified & Subtotal \\
\hline CA 05 & 1 year 3 months -1 year 6 months & Light brown & & 3 & & & & & 3 \\
\hline $\mathrm{CA} 05^{\mathrm{b}}$ & 1 year 3 months -1 year 6 months & Light brown & 1 & & & & & 1 & 2 \\
\hline CA 11 & 6 months & Mixed coat-brown dominant & 1 & & & & & & 1 \\
\hline CA 68 & 1 year & Dark brown & & 1 & & 3 & & 2 & 6 \\
\hline CA 134 & 6-9 months & Dark brown & & & & & 2 & 1 & 3 \\
\hline CA 136 & $3-6$ months & Mixed coat-brown dominant & 6 & 1 & 1 & & 1 & 6 & 15 \\
\hline CA 151 & 9 months -1 year & Light brown & 1 & & & & 1 & 3 & 5 \\
\hline CA 158 & 1 year & Mixed coat-brown dominant & 2 & & & & & & 2 \\
\hline CA 170 & 9 months & Dark brown & & & & & 1 & 1 & 2 \\
\hline CA 171 & 6-9 months & Light brown & 1 & & & & & & 1 \\
\hline CA 194 & 6 months & Dark brown & & & & & & 3 & 3 \\
\hline \multirow[t]{2}{*}{ CA 200} & 6-9 months & Light brown & 2 & 2 & & & & 4 & 8 \\
\hline & Subtotal & & 14 & 7 & 1 & 3 & 5 & 21 & 51 \\
\hline
\end{tabular}

${ }^{a}$ See text for discussion on identification.

${ }^{\mathrm{b}}$ Fecal sample. 
enables a centrifuge to separate the starch from the rest of the sediment by using a specific gravity that ensures that the starch floats or remains suspended. Fresh starch typically has a density of $1.5 \mathrm{~g} / \mathrm{ml}$, and therefore the specific gravity of the SPT was set at $1.7 \mathrm{~g} / \mathrm{ml}$. We did supernatant extraction two more times. Once the solution was clear, we transferred it to a clean slide. To mount the samples, we used a 50\% water and glycerin solution, which slows down the drying of the sample and makes it easier to rotate the starch grains. Finally, we placed a coverslip to seal the sample.

We observed the starch grains under a crosspolarized microscope (Nikon Eclipse E600 Pol) and took photographs and measurements using the software NIS-Elements. Starch grains were identified to genus and when possible to species, according to qualitative and quantitative criteria, which included the presence of the distinct extinction cross (a birefringent pattern visible under polarized light); the size of the grain; the angularity of the facets; and whether lamellae, fissures, or the hilum was visible. We took photographs of every starch grain at $600 \times$ in both cross-polarized light and transmitted light. We then compared the starch grains with a reference collection (Supplemental Table 1), located at MSH Mondes, that includes wild plants found along the coast and domesticated species previously reported in archaeobotanical contexts in the Andean region.

Of the 11 camelids we sampled, eight had already been sampled for SIA (Dufour et al. 2020). For the other three (CA-151, CA-171, CA-200; Supplemental Table 2), we prepared a fragment of bone (phalanx) and extracted collagen (gelatin) at the sclerochronology lab of the Muséum National d'Histoire Naturelle (MNHN), Paris, as described by Dufour and colleagues (2020). For $\delta^{13} \mathrm{C}$ and $\delta^{15} \mathrm{~N}$ and $\mathrm{C}$ and $\mathrm{N}$ content analysis, between 300 and $500 \mu \mathrm{g}$ of gelatin were combusted using an Elemental Analyser Flash 2000 coupled with a Delta V Advantage (Thermo Scientific) isotope ratio mass spectrometer, at the Service de Spectrométrie de Masse Isotopique du Muséum (SSMM) of the MNHN. We estimated the mass spectrometer analytical error to be $0.164 \%$ for $\delta^{13} \mathrm{C}$ and $0.083 \%$ for $\delta^{15} \mathrm{~N}$, based on replicate analysis of an internal standard (alanine; accepted $\delta^{13} \mathrm{C}$ $=-22.16 \%$ and $\delta^{15} \mathrm{~N}=+0.59 \%$ ) calibrated against the international standard IAEA 600. Analysis of sample CA-200 was repeated three times to test for intraindividual variability and analytical reproducibility and provided standard deviations of $0.060 \%$ and $0.032 \%$ for $\delta^{13} \mathrm{C}$ and $\delta^{15} \mathrm{~N}$, respectively. We used well-defined criteria to test for the quality of preservation of collagen: yield (wt \%), $\mathrm{C}$ and $\mathrm{N}$ content (\%), and the atomic C:N ratio (Ambrose 1990; DeNiro 1985; Dobberstein et al. 2009).

We estimated the relative contributions of $\mathrm{C}_{3}$ and $\mathrm{C}_{4}$ plants in the diet of the 11 camelids using a single Bayesian mixing model in the SIAR package (Parnell and Jackson 2013). Values of plants sampled in northern Peru by Szpak and colleagues (2014) were used as source values. We used a correction of $\sim 1.5 \%$ for modern source values to account for the Suess effect (Marino and McElroy 1991) and a collagendiet spacing value of $+3.6 \pm 1.7 \%$ for bone collagen (Szpak et al. 2014).

\section{Results}

In total, we recovered 51 starch grains from the 12 starch grain samples studied (Table 1). We also included in the final count starch grains ( $n=14$, plus a large cluster) that we found in 10 of the 33 gut samples tested for phytoliths (ongoing study). These latter grains could not be viewed in three dimensions, and therefore their identification remains tentative, but the breakdown is as follows: cf. maize $(n=5)$, cf. Prosopis sp. (algarrobo; $n=1$ ), a cluster of lenticular starch grains (not individually counted), and unidentified/damaged grains $(n=8)$.

The most numerous grains identifiable to genus or species belong to maize $(n=14)$ and were present in 7 of the 11 camelids studied. The grains are simple, with an open hilum, ranging from round to more polyhedral, and they have a continuous double border (Figure 3a-d). On average, the grains in the camelid samples measure $16.5 \mu \mathrm{m}$ in width.

A total of seven grains closely resembling those produced by chili peppers (Capsicum sp.), locally known as "aji," were identified from four camelids (Figure $3 \mathrm{e}-\mathrm{g}$ ). Moreover, in 

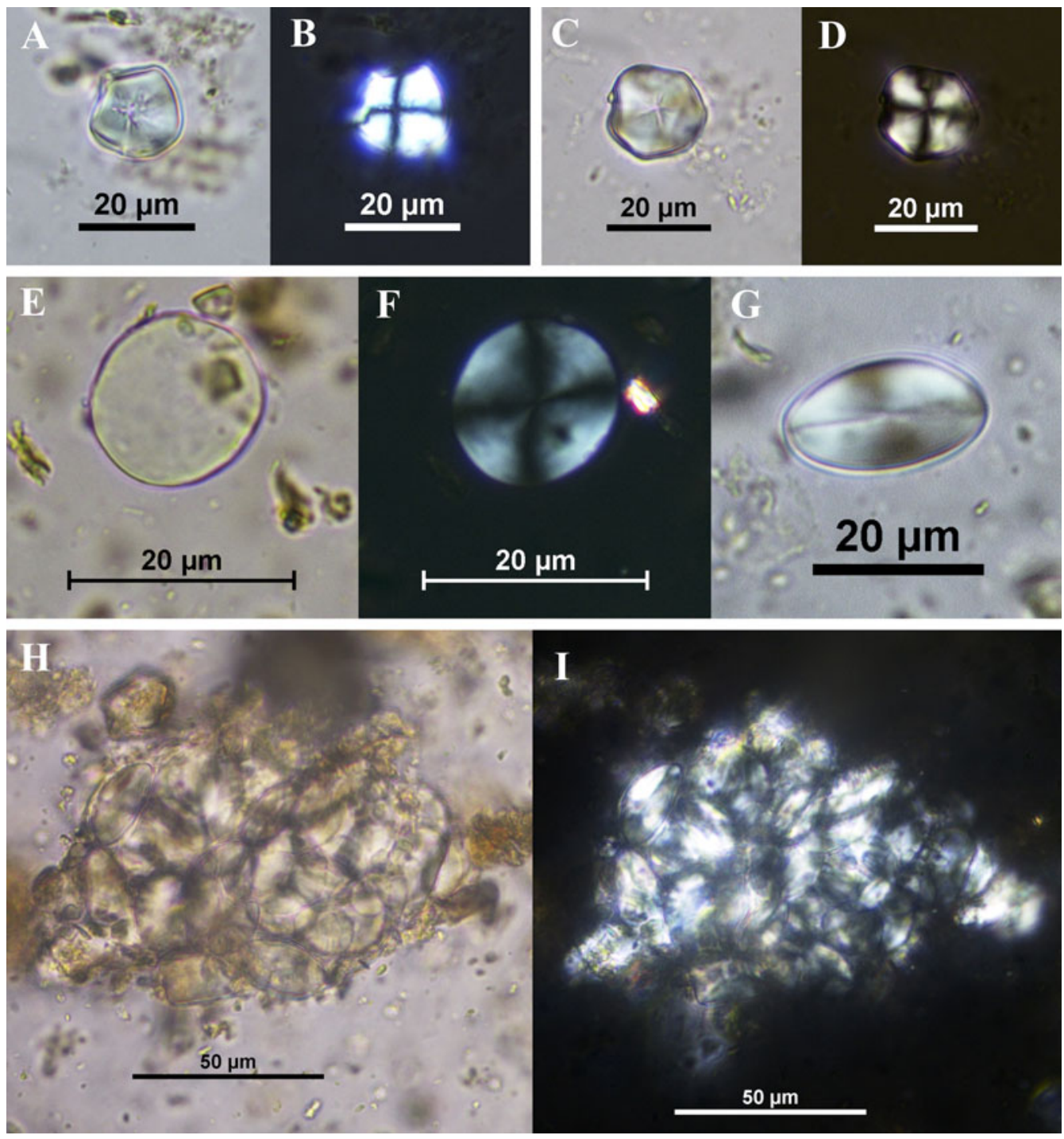

Figure 3. Starch grains viewed under transmitted and cross-polarized light. Maize starch grains from individuals CA-200 (a, b) and CA-05 (c, d). Lenticular starch grains from individuals CA-200 (e, g) and CA-171 (h, i). (Color online)

the sample of camelid CA-171, we found a large mass of fused lenticular grains (Figure $3 \mathrm{~h}, \mathrm{i}$ ). It remains unclear whether these grains belong to chili peppers or to a member of the Triticeae tribe, which produces similar grains to those of the chili pepper. Notably, starch grains produced by chili peppers are lenticular when viewed in plan view (see Figure 3a, b); in side view, they have a line that extends parallel to the long axis of the grain (see Figure 3g). They measure between 13 and $45 \mu \mathrm{m}$ in length (Perry et al. 2007). Only two genera in the Triticeae tribe are known to grow wild in the region: Hordeum and Elymus (Mostacero León et al. 2009). For the former genus, H. muticum is found in western South America, and H. pubiflorum is found in Peru (Bothmer et al. 2003); for the latter genus, three species are known from our region of interest: E. angulatus, E. cordilleranus, and E. hitchcockii. We do know that species in the genus Elymus tend to produce smaller starch grains (see Yang and Perry 2013), and in Peru, they tend to grow at higher altitudes (Mostacero León et al. 2009). Therefore, we can eliminate 
Elymus as a potential candidate. The size range of the starch grains in $\mathrm{H}$. muticum and $\mathrm{H}$. pubiflorum is currently unknown. The non-native wild Hordeum species (H. spontaneum, H. marinum) produce starch grains that measure between 6 and $26 \mu \mathrm{m}$ (Piperno et al. 2004), whereas domesticated barley (H. vulgare) produces grains that measure between 8 and $25 \mu \mathrm{m}$ (Henry et al. 2009). However, an identification as Hordeum is problematic because the grains from HLL seem to lack one characteristic that is well known for Hordeum starch grains: the presence of crater-like depressions on the surface.

We found additional taxa in smaller quantities. Five grains resembling those produced by algarrobo (Figure 4a, b), measuring on average $25 \mu \mathrm{m}$, were found in four of the camelids (CA-134, 136, 151, 170). Three grains of manioc were recovered from the gut sample of one camelid (CA-68; Figure 4c, d). The grains are bell shaped, with one to three basal facets, and measure
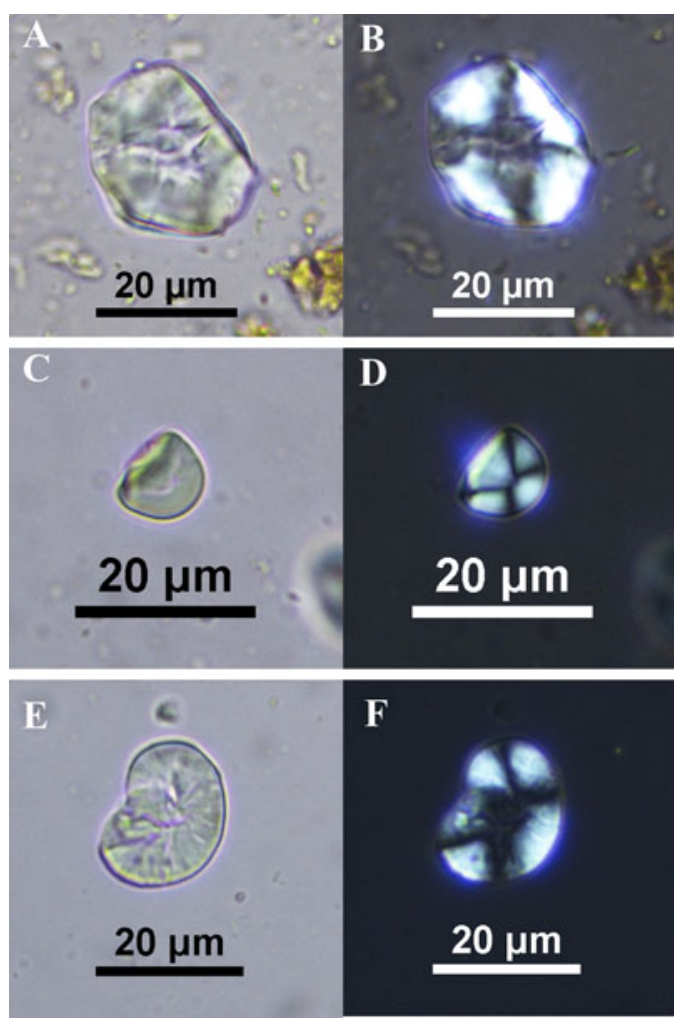

Figure 4. Various starch grains recovered from the gut samples, viewed under transmitted and cross-polarized light: (a, b) algarrobo (CA-170); (c, d) manioc (CA-68); and $(e, f)$ bean family (CA-136). (Color online) between 6 and $12.50 \mu \mathrm{m}$ in length. They are on the small end of the spectrum but still fall within published ranges (see Piperno and Holst 1998). We found one starch grain measuring $20 \mu \mathrm{m}$ in length belonging to the Fabaceae family, in camelid CA-136 (Figure 4e, f). Due to damage, it was not possible to identify it further, but it could belong to the domesticated bean (Phaseolus vulgaris) or the lima bean (P. lunatus).

We also found a total of 21 grains that could not be identified further, mainly due to damage, perhaps caused by the effects of mastication and digestion in the camelid gut. Some elements, such as the exploded hila seen on three starch grains (Figure 5a-c; Babot 2003; Cagnato 2019), suggest that the camelids may have been fed cooked foods. In another camelid, three fused starch grains clearly are in the process of gelatinization (Figure 5d, e). One mass of starch grains recovered from CA-151 resembles the elements commonly seen when starchy foods are exposed to heat (Figure 5f). In some cases, the extinction cross is less clear or absent (Figure 6a-h). In two camelids, the starch grains have small pits on their surface (Figure 6i-1). The cause of this damage is unclear.

In addition, $50 \%$ of the samples provided round pollen grains having a single pore and ring (annulus) and measuring on average $65 \mu \mathrm{m}$ wide. They belong to the Poaceae family, and we believe these are good candidates for maize pollen (Figure 7). The presence of maize pollen would be consistent with the predominance of starch grains that are likely also of this taxon in the final meal. Pollen grains of other morphotypes were present but in smaller quantities. They were not identified further in this study.

CA-151, CA-171, and CA-200, as did all other individuals selected for SIA, met the criteria defined for assessing the quality of preservation of bone collagen (Supplemental Table 2), confirming the very good state of preservation at HLL. Their $\delta^{13} \mathrm{C}$ and $\delta^{15} \mathrm{~N}$ values varied from $-13.9 \%$ to $-11.1 \%$ and from $+6.9 \%$ o to $+8.6 \%$, thus falling within the range of values measured previously for 82 other individuals from this site (Dufour et al. 2020). $\mathrm{C}_{4}$ plants dominate the diet of the 11 individuals sampled for starch grain analysis, with a mean contribution of $\mathrm{C}_{4}$ and $\mathrm{C}_{3}$ plants estimated to be $80.1 \%$ (95\% of the 

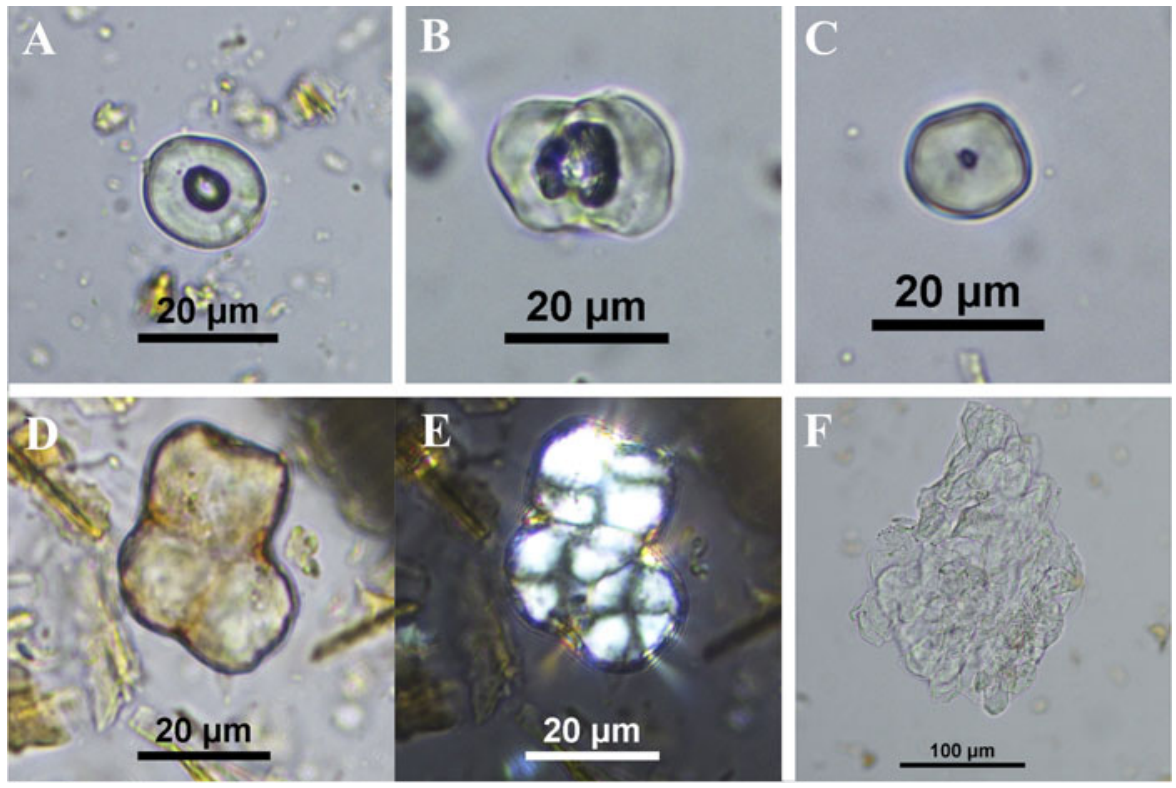

Figure 5. Damaged starch grains: (a) CA-134; (b) CA-178; (c) CA-11; (d, e) CA-200; and (f) CA-151. (Color online)
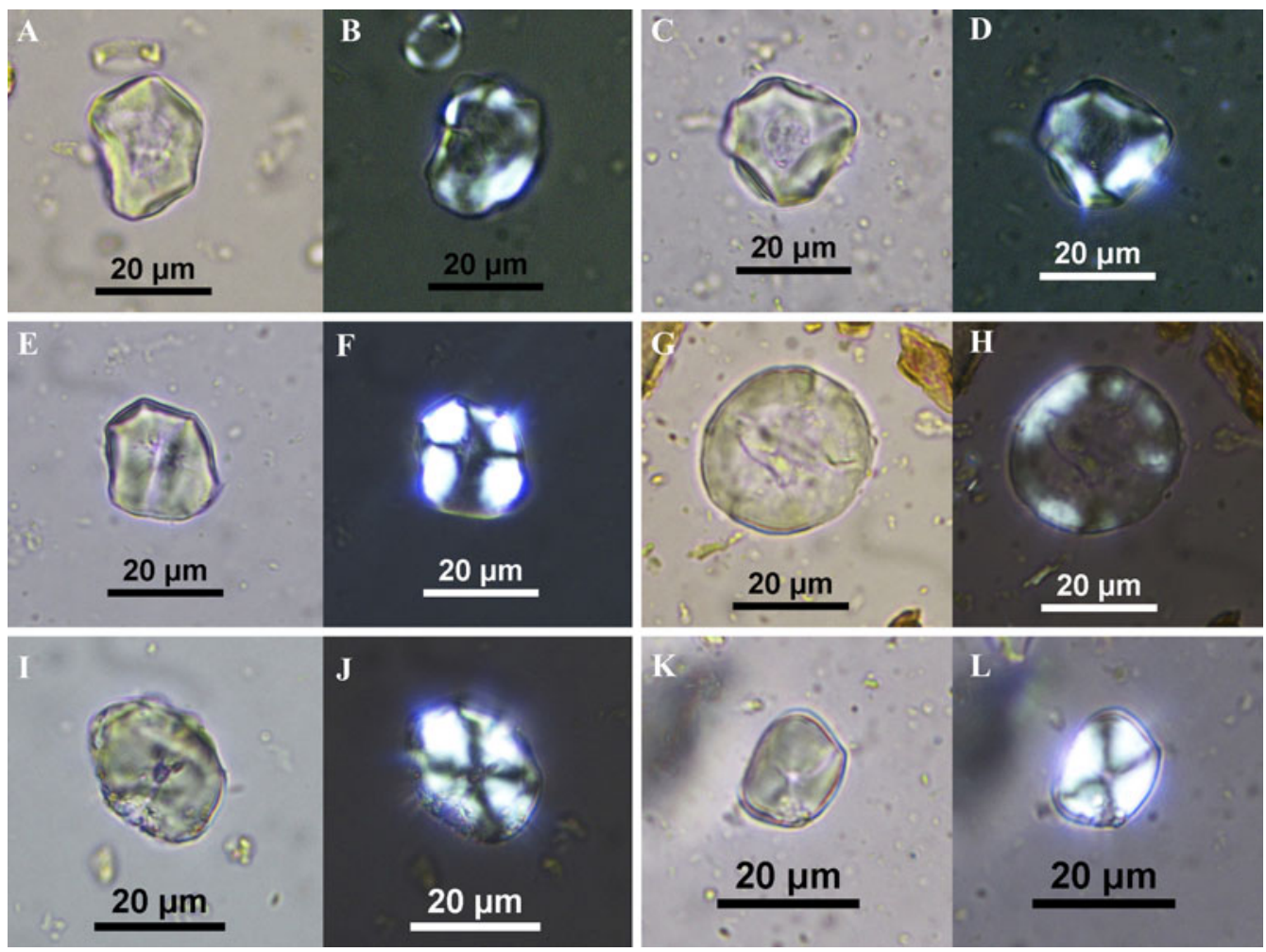

Figure 6. Damaged starch grains, viewed under transmitted and cross-polarized light: (a, b) CA-194; (c, d) CA-136; (e, f) CA-05f; (g, h) CA-151; (i, j) CA-151; and (k, l) CA-136. (Color online) 


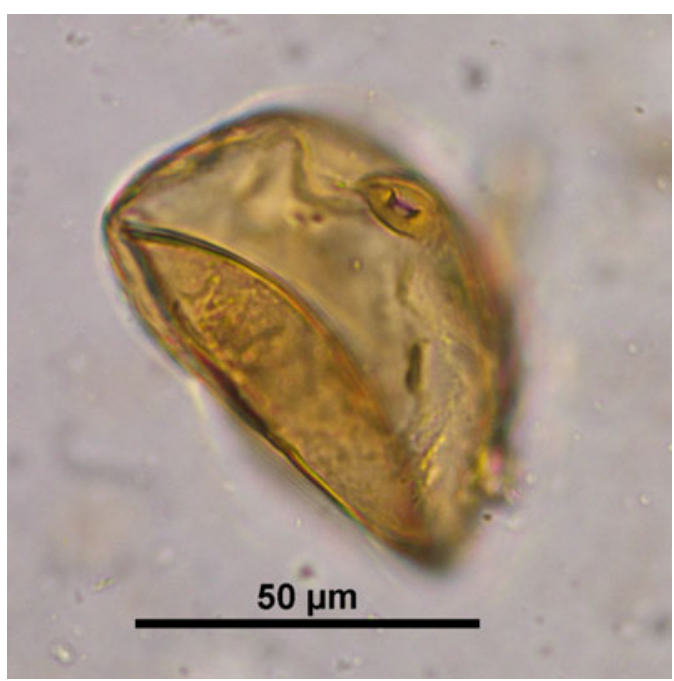

Figure 7. Probable maize pollen grain (CA-05). (Color online)

Bayesian credible interval: $72.3 \%-88.3 \%$ ) and $19.9 \%$ (95\% of the Bayesian credible interval: $11.7 \%-27.7 \%$ ), respectively (Figure 8). There is no correlation between the mean contribution of $\mathrm{C}_{4}$ plants to the diet and the presence of maize starch grains in the feces or gut contents.

\section{Discussion}

\section{Long-Term Camelid Diet at Huanchaquito-Las} Llamas

The gut contents of 11 HLL camelids and the feces of one camelid yielded 51 starch grains

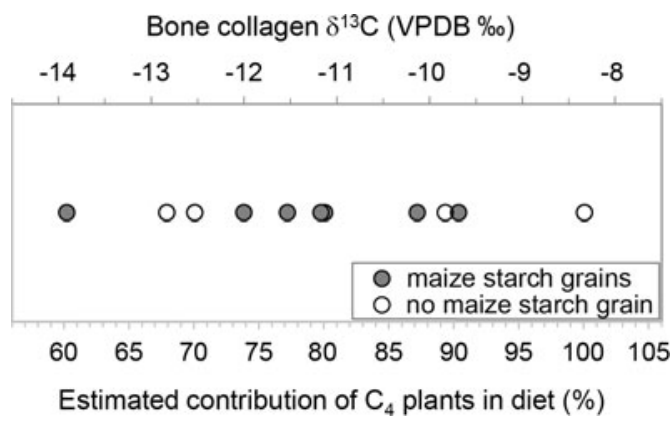

Figure 8. Plot of bone collagen $\delta^{13} \mathrm{C}$ values (\%, VPDB) and estimated proportion of $\mathrm{C}_{4}$ in the diet for the 11 domestic camelids from Huanchaquito-Las Llamas. The proportion of $\mathrm{C}_{4}$ in the diet was estimated using bone collagen $\delta^{13} \mathrm{C}$ values as defined in the text. The study of gut contents and feces provided maize starch grains for seven camelids (full circles) and no starch grains for four camelids (open circles). belonging to five taxa. Of these grains, $41 \%$ were not identifiable, and therefore it is possible that additional taxa may have been consumed. Making sense of these data is not straightforward because of the lack of comparative data. Today, camelids do not live on the coast of Peru, except for a modern herd raised at a low altitude at the Tinajones reservoir in the province of Lambayeque, where two of the authors (ED and NG) were able to observe some of its feeding habits. However, these animals have been subject to significant ecological adaptations. Historical data concerning the diet of camelids are not abundant, but those that do exist provide some interesting insights. Moreover, there are archaeobotanical data available, as well as SIA records that specifically targeted camelid dietary reconstruction.

In the present study, maize was the most ubiquitous taxon, its starch grains being present in 7 of 11 camelids. This is in accordance with the diet reconstructed through SIA, which indicates that these individuals consumed a large proportion of $\mathrm{C}_{4}$ plants over their lifetime (see Supplemental Table 2 and Figure 8). Maize has been widely reported in various forms in Andean archaeology (Bonavia 2008b; Haas et al. 2013). It was present as early as $6700 \mathrm{BP}$ on the northern coast of Peru (Grobman et al. 2012) and was already a staple in this part of Peru by the fifteenth century AD (Masur et al. 2018). The Chimú developed intensive agriculture using an extensive hydraulic system (Farrington and Park 1978; Ortloff 1981), and maize was an essential component of their diet and culture. Historical sources indicate that camelids ate maize when it was given to them, but that otherwise they would graze on whatever they could find. A drawing by chronicler Guamán Poma de Ayala (2005 [1615]:919) shows a llama in a field eating maize, and Squier (1877) witnessed corralled llamas being fed maize kernels in the highlands. This practice seemingly continues, being observed among current llama breeders (Shimada and Shimada 1985). Archaeologically, maize has been reported in various forms from camelid coprolites: pollen from llama excrements at PV35-4, a Middle Horizon site (Jones 1990), and maize stomata and other diagnostic features from feces at Huaca 1, a LIP site (Bonavia 2008a). Our starch grain data clearly 
indicate that maize kernels were consumed by the camelids, because it was their guts that contained the starch grains.

The SIA of archaeological remains has suggested that there was long-term foddering of animals with maize in the Lowlands during the Mochica period at the Uhle Platform (Dufour et al. 2014) and at sites dated from the Early Intermediate period (EIP) to the LIP in the Virú and Chicama Valleys (Santana-Sagredo et al. 2020; Szpak et al. 2020). Foddering could have been a method used by the lowland herders to compensate for the limited productivity of coastal habitats, and, more widely, it may have been the usual camelid management strategy in the Andes. It was observed at the highland site of Conchopata $(2,700 \mathrm{~m}$ asl), where maize was an important staple in the economy of the Wari polity (AD 550-1000; Finucane et al. 2006). There are thus some converging indications that maize could have been a common element in the camelid diet, but earlier records were unable to document which part of the plant was consumed. The consumption of maize kernels indicated by our study is significant because of their high caloric value compared with maize byproducts, such as stalks.

$\mathrm{C}_{4}$ plants other than maize may have contributed to the high $\delta^{13} \mathrm{C}$ values of the HLL camelids, including cultivated Amaranthus sp. and wild grasses and sedges. Grama salada, which is part of the plant community type called Gramadales, has a wide distribution in areas close to the sea and on dunes (Mostacero León et al. 2009). According to Thornton and colleagues (2011), this salt-tolerant grass, as well as dropseed (Sporobolus rigens), is consumed by both wild and domestic camelids. However, the consumption of these non-maize plants does not appear to be sufficient to support the daily feeding of large herds and to explain a $\mathrm{C}_{4}$ contribution as high as the $70 \%$ observed for the sacrificed animals at HLL.

Starch grains of algarrobo were recovered from four of the camelids from HLL and therefore represent the second most frequent plant recovered from the samples. Starch grains are only found in the mesocarp (the fleshy pulp surrounding the seed) of the algarrobo pod; therefore, the HLL camelids clearly consumed its pods. Algarrobo seeds and other tissues were reported from llama feces from archaeological contexts previously (Bermeo 2017; Bonavia 2008a). In the province of Lambayeque, endocarps and seeds were found in llama dung dating to the LIP (Bonavia 2008a; Shimada and Shimada 1985). We observed a few modern adult llamas from the Tinajones herd feeding on algarrobo pods and leaves, but because they were only from one herd, it is difficult to know whether this habit could be common. The practice of foddering livestock was mentioned by Capparelli and Lema (2011:83). Algarrobo may have been an important staple, because it is not solely recorded for camelids: it was also found in the gut contents of human mummies (Holden and Núñez 1993); in human coprolites in the Ica Valley of Peru (Beresford-Jones et al. 2011); and in preceramic contexts at Buena Vista, notably as residue inside organic containers recovered from feasting contexts dated to about $2200 \mathrm{cal}$ BC (Duncan et al. 2009).

\section{The Unexpected Ritual Foods}

Although maize and algarrobo may be easily recognized as regular staple foods for camelids, the presence of manioc and chili peppers was not intuitive. Evidence for manioc has been recovered from various places and from different time periods along the coast of Peru in the form of dried roots, starch grains, and phytoliths (Duncan et al. 2009; Ikehara et al. 2013; Prieto 2020; Ugent et al. 1986), and it is depicted rather ubiquitously on ceramics from the Chimú period. Manioc tubers can be ground into flour to prepare bread and can be made into a fermented beverage (Duncan et al. 2009). The bitter and the sweet varieties are the same species; their only difference is their differing concentrations of cyanogenic glucosides (Isendahl 2011). It remains unclear whether the sweet, the bitter, or both varieties were consumed along the coast of Peru in prehispanic times (Prieto 2020; Ugent et al. 1986). Yet if camelids ingested the bitter variety raw, it could have resulted in cyanide intoxication, which can cause dizziness, vomiting, and even death (Isendahl 2011). Moreover, because camelids "do not uproot vegetation with their feet, and never destroy stems and roots" (Bonavia 2008a:399), it seems unlikely they 
dug up the manioc root while the herd was kept in pens or fields. It is more probable that sweet or bitter manioc was intentionally given to them by Chimú herders before their ritual killing.

Finally, we present the first tentative evidence of the ingestion of chili peppers by camelids. This spicy plant, considered sacred by the Inca, has been found in both domestic and ritual contexts across the Andean region (Beresford-Jones et al. 2011; Chiou et al. 2014; Pickersgill 1969). As with manioc, chili peppers are depicted on Chimú ceramics. However, the identification of their lenticular starch grains is complicated because of the similarities between the starch grains produced by the Triticeae tribe grasses and those produced by chili peppers. Although the little surface craters/pits are absent on the starch grains in the archaeological samples (seemingly indicating that these are not likely to be grass starches), we also need to consider the effects that mastication and digestive processes may have had on these microbotanical remains. Although it would seem more plausible, given the ritual circumstances, that the animals would have been fed or would have naturally grazed on wild Hordeum, it is not impossible to imagine that special foods or unusual food preparations, including chili peppers, may have been given or fed to them before their death.

Beans were of course consumed by humans. In northern Peru, starch grains of the genus Phaseolus are reported from dental calculus recovered from an early and middle Holocene human settlement in the Nanchoc Valley (Piperno and Dillehay 2008), and bean cotyledons and pods were also documented from the Virú Valley (Masur et al. 2018). The only evidence to date for the Fabaceae family is the presence of Vicia sp. pollen in one llama coprolite sample from a preceramic site on the northcentral coast of Peru (Jones and Bonavia 1992). There are no known historical accounts of camelids consuming beans in Peru and more generally in the Andes.

\section{Consumption of Cooked Food}

Another interesting result is evidence for the ingestion of different preparations of food, including possibly cooked foods. The starch grains recovered from the samples generally retained their shape, even after mastication, ingestion, and digestion. It is known that starch digestion is complex and that a range of factors influence this process (Tester et al. 2006). Uncooked starch will break down more slowly than cooked starch (Copeland and Hardy 2018), because raw starch resists digestion by the $\alpha$-amylase enzyme present in the mouth and gut (Tester et al. 2006). The presence of relatively unaltered grains in the samples may suggest that some of the foods eaten by the camelids were raw, although it is also possible that these seemingly intact grains resisted cooking processes (Crowther 2012). The presence of a gelatinized starch mass and other diagnostic damage that is often seen in cooked plant foods (Babot 2003; Vinton et al. 2009) are more secure indicators that cooked foods were also given to the camelids. Providing cooked foods to the camelids could have been a special practice because of the ritual nature of the event. Another issue that should be considered is whether these foods were consumed as solids or liquids. If the animals were fed some of these plants, we can imagine that they were forced to drink, rather than to eat. The discovery of ceramic vessels, together with wooden paddles, at HLL may be related to the consumption of maize beer, or chicha, during the sacrifice (Prieto et al. 2019), and the presence of maize starch grains in the camelids' guts suggests that it is possible that the camelids were given this drink. Chicha was important in both the domestic and the ritual sphere (Jennings and Bowser 2009). Since prehispanic times, chicha was prepared not only for daily consumption but also as a key element in ritual and political events (Hayashida 2008). Different types of evidence exist to support the production of chicha (see Hayashida 2008; Vásquez et al. 2018), including its flavoring with a variety of fruits (Prieto 2011). The recovery of maize starch grains from feasting vessels from a coastal Peruvian site has been argued to be indicative of events that served to integrate the community through the increased consumption of maize (Ikehara et al. 2013). None of the starch grains recovered from the HLL samples exhibit the damage seen on the starches of maize that had been subjected to experimental fermentation by Vinton and colleagues (2009). However, 
some of the starch grains (Figure 6) do exhibit peculiar damage that has not been seen previously by the first author and that could be the result of some special preparation of the maize given to the camelids.

\section{A Final, Special Meal for the Huanchaquito-Las Llamas Camelids}

The sacrifice at HLL necessitated the provisioning of a large number of animals. High variability in both $\delta^{13} \mathrm{C}$ and $\delta^{15} \mathrm{~N}$ values shows that these young, sacrificed camelids were raised locally on the coast or in the middle valleys and that they most likely originated from different herds that were segregated from each other (Dufour et al. 2020; Prieto et al. 2019). The ritual practices and possible management by the Chimú officiants of these animals before their sacrifice may have included keeping them together for a short period and feeding them a special diet. Although collagen analysis cannot be used to infer short-term dietary changes, microbotanical analysis can give us a snapshot of the last meal: the remains of the last 48 hours should be represented in the gut. Alpacas, for example, retain their food in their digestive tract for about 50 hours (Sánchez Reyes 2004). Based on what we know about their diet throughout their life (by SIA of their bone collagen) and about the last foods they ate (by studying the starch grains present in their gut and feces) we were able to establish that, shortly before their death, the camelids consumed a broader range of plants than expected. The animals may have been corralled some hours or days before being sacrificed, as evidenced by the remnants of special food that consisted of manioc, beans, and possibly chili peppers and some cooked foods, as well as of foods that were part of their usual diet. Shortly before death, most of the young camelids ( 7 of 11) consumed maize, a food that they had likely fed on regularly, as evidenced by the high estimated $\mathrm{C}_{4}$ plant contribution. A few also ate algarrobo, which again seems to have been a normal practice when we consider the archaeobotanical and historical record. None of the plants identified in the samples appear to have been imported, because all these taxa could have been grown locally. Chimú society expanded throughout the Moche Valley to take advantage of its fertile fields for growing maize, chili peppers, and coca, as well as the naturally growing bosque seco (algarrobo, acacia). The bosque seco is today a highly threatened forest ecosystem, but, as noted by Rostworowski (1981), it was more prevalent in the past. Therefore, these plants were likely accessible by the inhabitants of the coast.

How did the camelids gain access to these foods before their sacrifice? As we note earlier, one option would be for herders to bring maize - including kernels - and other foods directly to the animals selected for sacrifice. Alternatively, the presence of maize pollen grains in the camelid gut contents suggests that these animals were likely present in or in the vicinity of maize fields or that they were left to forage on maize cobs or graze on the stalks and leaves. Regardless of how the pollen arrived in the camelid guts, occasional foraging in the fields is not enough to explain the high $\mathrm{C}_{4}$ proportions as determined by SIA. Our combined approach allows us to propose with greater certainty the possibility that the camelids were foddered during their lifetime and received special foods, even ritually significant foods, before their sacrifice. Similarly, it could contribute much to the knowledge of the ritual sequence accompanying human sacrifices and to that of more common dietary practices.

\section{Conclusions}

Because this is the first and, therefore, an exploratory study carried out on starch grains from desiccated camelid gut contents, it was initially unclear whether these microbotanical remains would be preserved and in what condition. Based on our results, we can confirm that starch grain analysis can be successfully carried out on gut contents to determine what foods were part of a camelid's final meal. Combining these data with other types of analyses - the study of phytoliths and pollen-will provide additional important information regarding the identification of consumed taxa.

The very good preservation of the faunal remains and the interdisciplinary study carried out on this particular archaeological collection show the full potential of this type of approach. 
By combining the identification of starch grains with SIA, we were able to elucidate the diet of the sacrificed camelids over both the long and short term. The major presence of maize starch grains is consistent with the isotopic results and suggests the importance of this plant to the animals' diet throughout their life and until their final diet. We document both how the Chimús managed their herds and that they also reserved special treatment for those animals destined for sacrifice. Probably gathered a few hours or days before the sacrificial act, these camelids, which came from different herds, benefited from a special diet, with the addition of unusual foods that included manioc, chili peppers, and beans, some of which may have been cooked as part of a prepared meal. Although we do not know the specific reasons why these plants or meals were chosen and given to the camelids, we could argue that the presence of these particular plants suggests their importance in the ritual.

There is no doubt that the analysis of gut remains shows great potential to provide new insights into camelid management and ritual practices. However, such analysis can also be applied to studying human diets in ritual contexts. In the case of HLL, we were able to establish the ritual sequence a few hours or days before the camelid sacrifice. The use of animals in ancient rituals in the Andes and across the American continent is well attested; in some cases, these animals may even have been held in captivity and fed a special diet before the ritual event (Emery 2004; Sugiyama et al. 2015). Future applications of starch grain analysis in the study of well-preserved animal remains may prove fruitful to reconstruct management practices and ancient rituals and to demonstrate whether standardized practices existed in the past. Similarly, such analysis could contribute much to our knowledge about the ritual sequence accompanying human sacrifices or, indeed, of more mundane dietary practices.

Acknowledgments. This work was supported by the ANR CAMELANDES under Grant ANR-15-CE27-0002 and AASPE (UMR 7209 MNHN-CNRS). We thank the ArchéoScopie department at the MSH Mondes in Nanterre (France) for providing access to the imaging equipment. We are grateful to Olivier Tombret (UMR 7209) for his help in the laboratory during sample preparation and to Denis Fiorillo (UMR 7209 , SSMIM) for the stable isotope analysis. We also thank the Municipalidad Distrital de Huanchaco, the Department of Anthropology at Yale University, the National Geographic Society, INNOVATE PERU, Fondecyt-Concytec Perú-Banco Mundial, and Universidad Nacional de Trujillo for providing funds for the excavations at HLL. We are grateful to Belkys Gutiérrez Léon (BGL Arqueología, Peru) for her help with administrative issues, Jean-François Cuénot (UMR 8096, CNRS, France) for processing the map on ArcGIS, and Juan Plengue from the Reserva Chaparri for his assistance during the visit to Tinajones. We would also like to thank the anonymous reviewers and the editor for their constructive remarks.

Data Availability Statement. The processed starch grain samples are stored and available at the MSH Mondes. The original samples of the gut contents are available for some of the camelids only and are also stored at the MSH Mondes. The isotopic values are available in this article and in Dufour and colleagues (2020).

Supplemental Materials. For supplemental material accompanying this article, visit https://doi.org/10.1017/laq.2021.19.

Supplemental Table 1. List of the South American Plants in the MSH Mondes Reference Collection that Produce Starch Grains.

Supplemental Table 2. Isotopic Values of Camelids from Huanchaquito-Las Llamas.

\section{References Cited}

Ambrose, Stanley H.

1990 Preparation and Characterization of Bone and Tooth Collagen for Isotopic Analysis. Journal of Archaeological Science 17:431-451.

Andrushko, Valerie A., Michele R. Buzon, Arminda M. Gibaja, Gordon R. McEwan, Antonio Simonetti, and Robert A. Creaser

2011 Investigating a Child Sacrifice Event from the Inca Heartland. Journal of Archaeological Science 38:323-333.

Babot, Maria del Pilar

2003 Starch Grain Damage as an Indicator of Food Processing. In Phytolith and Starch Research in the Australian-Pacific-Asian Regions: The State of the Art, Vol. 19, edited by Diane M. Hart and Lynley A. Wallis, pp. 69-81. Pandanus Press, Australian National University, Canberra.

Beresford-Jones, David G., Oliver Whaley, Carmela Alarcón Ledesma, and Lauren Cadwallader

2011 Two Millennia of Changes in Human Ecology: Archaeobotanical and Invertebrate Records from the Lower Ica Valley, South Coast Peru. Vegetation History and Archaeobotany 20:273-292.

Bermeo, Nicolas

2017 Rapport d'étude du matériel carpologique. In Rapport sur la campagne 2017 Huaca Amarilla et Huaca Grande, edited by Nicolas Goepfert, pp. 61-64. Ministère des Affaires Étrangères, Paris.

Bonavia, Duccio

2008a The South American Camelids. Cotsen Institute of Archaeology, University of California, Los Angeles.

2008b El maíz: Su origen, su domesticación y el rol que ha cumplido en el desarrollo de la cultura. Universidad de San Martín de Porres, Lima. 
Bothmer, Roland von, Kazuhiro Sato, Takao Komatsuda, Shozo Yasuda, and Gerhard Fischbeck

2003 The Domestication of Cultivated Barley. In Diversity in Barley (Hordeum vulgare), edited by Roland von Bothmer, Theo van Hintum, Helnut Knüpffer, and Kazuhiro Sato, pp. 9-27. Elsevier Science, Amsterdam.

Cagnato, Clarissa

2019 Hervir y moler: Descifrando técnicas de elaboración de alimentos, a través del análisis microscópico de los granos de almidón recolectados en contextos arqueológicos mesoamericanos. Itinerarios 29(1):9-33.

Cagnato, Clarissa, and Jocelyne M. Ponce

2017 Ancient Maya Manioc (Manihot esculenta Crantz) Consumption: Starch Grain Evidence from Late to Terminal Classic (8th-9th Century CE) Occupation at La Corona, Northwestern Petén, Guatemala. Journal of Archaeological Science: Reports 16:276-286.

Capparelli, Aylen, and Verónica Lema

2011 Recognition of Post-Harvest Processing of Algarrobo (Prosopis spp.) as Food from Two Sites of Northwestern Argentina: An Ethnobotanical and Experimental Approach for Desiccated Macroremains. Archaeological and Anthropological Sciences 3:71-92.

Caruso Fermé, Laura, Nadia J. Velázquez, A. Cecilia Martínez Tosto, Cristina Yagueddú, L. Susana Burry, and $\mathrm{M}$. Teresa Civalero

2018 Multiproxy Study of Plant Remains from Cerro Casa de Piedra 7 (Patagonia, Argentina). Quaternary International 463:327-336.

Chiou, Katherine L., Christine A. Hastorf, Duccio Bonavia, and Tom D. Dillehay

2014 Documenting Cultural Selection Pressure Changes on Chile Pepper (Capsicum baccatum L.) Seed Size through Time in Coastal Peru (7,600 BP-Present). Economic Botany 68:190-202.

Collin Delavaud, Claude

1984 Las regiones costeñas del Perú Septentrional: Ocupación humana, desarrollo regional. PUCP, Lima.

Copeland, Les, and Karen Hardy

2018 Archaeological Starch. Agronomy 8(1):4. DOI:10. 3390/agronomy 8010004 .

Crowther, Alison

2012 The Differential Survival of Native Starch during Cooking and Implications for Archaeological Analyses: A Review. Archaeological and Anthropological Sciences 4:221-235.

DeNiro, Michael J.

1985 Postmortem Preservation and Alteration of in vivo Bone Collagen Isotope Ratios in Relation to Palaeodietary Reconstruction. Nature 317:806-809.

DeNiro, Michael J., and Samuel Epstein

1978 Influence of Diet on the Distribution of Carbon Isotopes in Animals. Geochimica et Cosmochimica Acta 42:495-506.

Dickau, Ruth, Anthony J. Ranere, and Richard G. Cooke

2007 Starch Grain Evidence for the Preceramic Dispersals of Maize and Root Crops into Tropical Dry and Humid Forests of Panama. PNAS 104:3651-3656.

Dobberstein, Reimer C., Matthew J. Collins, Oliver E. Craig, Gillian Taylor, Kirsty E. H. Penkman, and Stefanie RitzTimme

2009 Archaeological Collagen: Why Worry about Collagen Diagenesis? Archaeological and Anthropological Sciences 1:31-42.

Dufour, Elise, Nicolas Goepfert, Belkys Gutiérrez Léon, Claude Chauchat, Regulo Franco Jordan, and Segundo
Vásquez Sánchez

2014 Pastoralism in Northern Peru during Pre-Hispanic Times: Insights from the Mochica Period (100-800 AD) Based on Stable Isotopic Analysis of Domestic Camelids. PLoS ONE 9(1):e87559.

Dufour, Elise, Nicolas Goepfert, Manon Le Neün, Gabriel Prieto, and John W. Verano

2020 Life History and Origin of the Camelids Provisioning a Mass Killing Sacrifice during the Chimú Period: Insight from Stable Isotopes. Environmental Archaeology 25:310-324.

Duncan, Neil A., Deborah M. Pearsall, and Robert A. Benfer 2009 Gourd and Squash Artifacts Yield Starch Grains of Feasting Foods from Preceramic Peru. PNAS 106:13202-13206.

Emery, Kitty F.

2004 Animals from the Maya Underworld: Reconstructing Elite Maya Ritual at the Cueva de los Quetzales, Guatemala. In Behaviour behind Bones: The Zooarchaeology of Ritual, Religion, Status and Identity, edited by Sharyn Jones O'Day, Wim Van Neer, and Anton Ervynck, pp. 101-113. Oxbow Books, Oxford.

Farrington, Ian S., and Chris C. Park

1978 Hydraulic Engineering and Irrigation Agriculture in the Moche Valley, Peru: c. A.D. 1250-1532. Journal of Archaeological Science 5:255-268.

Finucane, Brian, Patricia M. Agurto, and William H. Isbell

2006 Human and Animal Diet at Conchopata, Peru: Stable Isotope Evidence for Maize Agriculture and Animal Management Practices during the Middle Horizon. Journal of Archaeological Science 33:17661776.

Flores Ochoa, Jorge A., Kim MacQuarrie, and Javier Portus 1994 Oro de los Andes: Las llamas, alpacas, vicuñas y guanacos de Sudamérica. 2 vols. Jordi Blassi, Barcelona.

Goepfert, Nicolas

2011 Frayer la route d'un monde inversé: sacrifice et offrandes animales dans la culture Mochica (100- 800 apr. J.-C.), côte nord du Pérou. BAR International Series 2278. British Archaeological Reports, Oxford.

2012 New Zooarchaeological and Funerary Perspectives on Mochica Culture (AD 100-800), Peru. Journal of Field Archaeology 37:104-120.

Goepfert, Nicolas, Elise Dufour, Gabriel Prieto, and John Verano

2020 Herds for the Gods? Selection Criteria and Herd Management at the Massive Sacrifice Site of Huanchaquito-Las Llamas during the Chimú Period, Northern Coast of Peru. Environmental Archaeology 25:296-309.

Goepfert, Nicolas, and Gabriel Prieto

2016 Offering Llamas to the Sea. In The Archaeology of Andean Pastoralism, edited by José M. Capriles and Nicolas Tripcevich, pp. 197-210. University of New Mexico Press, Albuquerque.

Gott, Beth, Huw Barton, Delwen Samuel, and Robin Torrence 2006 Biology of Starch. In Ancient Starch Research, edited by Robin Torrence and Huw Barton, pp. 35-46. Left Coast Press, Walnut Creek, California.

Grobman, Alexander, Duccio Bonavia, Tom Dillehay, Dolores R. Piperno, Jose Iriarte, and Irene Holst

2012 Preceramic Maize from Paredones and Huaca Prieta, Peru. PNAS 109:1755-1759.

Guamán Poma de Ayala, Felipe

2005 [1615] Nueva corónica y buen gobierno Tomo II. Fondo de Cultura Economica, Mexico City. 
Haas, Jonathan, Winifred Creamer, Luis Huamán Mesía, David Goldstein, Karl Reinhard, and Cindy Vergel Rodríguez

2013 Evidence for Maize (Zea mays) in the Late Archaic (3000-1800 B.C.) in the Norte Chico Region of Peru. PNAS 110:4945-4949.

Haslam, Michael

2004 The Decomposition of Starch Grains in Soils: Implications for Archaeological Residue Analyses. Journal of Archaeological Science 31:1715-1734.

Hayashida, Frances M.

2008 Ancient Beer and Modern Brewers: Ethnoarchaeological Observations of Chicha Production in Two Regions of the North Coast of Peru. Journal of Anthropological Archaeology 27:161-174.

Henry, Amanda G., Holly F. Hudson, and Dolores R. Piperno 2009 Changes in Starch Grain Morphologies from Cooking. Journal of Archaeological Science 36:915-922.

Holden, Timothy G., and Lautaro Núñez

1993 An Analysis of the Gut Contents of Five WellPreserved Human Bodies from Tarapacá, Northern Chile. Journal of Archaeological Science 20:595-611.

Ikehara, Hugo C., J. Fiorella Paipay, and Koichiro Shibata

2013 Feasting with Zea mays in the Middle and Late Formative North Coast of Peru. Latin American Antiquity 24:217-231.

Isendahl, Christian

2011 The Domestication and Early Spread of Manioc (Manihot esculenta Crantz): A Brief Synthesis. Latin American Antiquity 22:452-468.

Jennings, Justin, and Brenda J. Bowser

2009 Power and Society in the Andes. University Press of Florida, Gainesville.

Jones, John G.

1990 Results of the Analysis of Palynological Investigation of Camelid Feces from Peru. Manuscript on file, Department of Anthropology, Texas A\&M University, College Station.

Jones, John G., and Duccio Bonavia

1992 Análisis de coprolitos de llama (Lama glama) del Precerámico tardío de la Costa Norcentral del Perú. Bulletin de l'Institut Français d'Études Andines 21:835-852.

Klaus, Haagen D., and J. Marla Toyne (editors)

2016 Ritual Violence in the Ancient Andes: Reconstructing Sacrifice on the North Coast of Peru. University of Texas Press, Austin.

Korstanje, M. Alejandra

2005 Microfossils in Camelid Dung: Taphonomic Considerations for the Archaeological Study of Agriculture and Pastoralism. In Biosphere to Lithosphere: New Studies in Vertebrate Taphonomy, edited by Terry O'Connor, pp. 70-78. Oxbow Book, Oxford.

Le Bailly, Matthieu, Nicolas Goepfert, Gabriel Prieto, John Verano, and Benjamin Dufour

2020 Camelid Gastrointestinal Parasites from the Archaeological Site of Huanchaquito (Peru): First Results. Environmental Archaeology 25:325-332.

Marino, Bruno D., and Michael B. McElroy

1991 Isotopic Composition of Atmospheric CO 2 Inferred from Carbon in C4 Plant Cellulose. Nature 349: 127-131.

Masur, Lindi J., Jean-François Millaire, and Michael Blake

2018 Peanuts and Power in the Andes: The Social Archaeology of Plant Remains from the Virú Valley, Peru. Journal of Ethnobiology 38:589-610.

Moore, Jerry D., and Carol J. Mackey

2008 The Chimú Empire. In The Handbook of South
American Archaeology, edited by Helaine Silverman and William H. Isbell, pp. 783-807. Springer, New York.

Mosca Torres, M. Eugenia, Silvana V. Urquiza, and Carlos A. Aschero

2018 Microhistological Analysis of Ancient Camelid Dung from the Southern Argentinean Puna: Past Vegetation Composition and Diet. Journal of Archaeological Science: Reports 20:347-354.

Mostacero León, José, Freddy Mejía Coico, and Oscar Gamarra Torres

2009 Fanerógamas del Perú: Taxonomía, utilidad y ecogeografía. CONCYTEC, Trujillo, Peru.

Ortloff, Charles R.

1981 La ingeniería hidraúlica Chimú (Parte I): El sistema de canales La Cumbre. In La tecnología en el mundo andino: Subsistencia y mensuración, edited by Heather Lechtman and Ana Maria Soldi, pp. 91-134. UNAM, Mexico City.

Parnell, Andrew C., and Andrew L. Jackson

2013. SIAR: Stable Isotope Analysis in R. R. Package Version 4.2. http://CRAN.R-project.org/package=siar, accessed December 2, 2019.

Perry, Linda, Ruth Dickau, Sonia Zarrillo, Irene Holst, Deborah M. Pearsall, Dolores R. Piperno, Mary Jane Berman, Richard G. Cooke, Kurt Rademaker, Anthony J. Ranere, J. Scott Raymond, Daniel H. Sandweiss, Franz Scaramelli, Kay Tarble, and James A. Zeidler

2007 Starch Fossils and the Domestication and Dispersal of Chili Peppers (Capsicum spp. L.) in the Americas. Science 315:986-988.

Pickersgill, Barbara

1969 The Archaeological Record of Chili Peppers (Capsicum spp.) and the Sequence of Plant Domestication in Peru. American Antiquity 34:54-61.

Piperno, Dolores R., and Tom Dillehay

2008 Starch Grains on Human Teeth Reveal Early Broad Crop Diet in Northern Peru. PNAS 105:19622-19627.

Piperno, Dolores R., and Irene Holst

1998 The Presence of Starch Grains on Prehistoric Stone Tools from the Humid Neotropics: Indications of Early Tuber Use and Agriculture in Panama. Journal of Archaeological Science 25:765-776.

Piperno, Dolores R., Ehud Weiss, Irene Holst, and Dani Nadel

2004 Processing of Wild Cereal Grains in the Upper Palaeolithic Revealed by Starch Grain Analysis. Nature 430:670-673.

Prieto, Gabriel

2011 Chicha Production during the Chimú Period at San José de Moro, Jequetepeque Valley, North Coast of Peru. In From State to Empire in the Prehistoric Jequetepeque Valley, Peru, edited by Colleen M. Zori and Ilana Johnson, pp. 105-128. BAR International Series No. 2310. Archaeopress, Oxford.

2020 The Fisherman's Garden: Horticultural Practices in a Second Millennium Maritime Community of the North Coast of Peru. In Maritime Communities of the Ancient Andes, edited by Gabriel Prieto and Daniel H. Sandweiss, pp. 218-246. University Press of Florida, Gainesville.

Prieto, Gabriel, John W. Verano, and Nicolas Goepfert

2017 Lluvias e inundaciones en el siglo XV de nuestra era: Sacrificios humanos y de camélidos Chimú en la periferia de Chan Chan. In Actas del II Congreso Nacional de Arqueología, pp. 55-65. Ministerio de Cultura, Lima.

Prieto, Gabriel, John W. Verano, Nicolas Goepfert, Douglas Kennett, Jeffrey Quilter, Steven Leblanc, Lars Fehren-Schmitz, Jannine Forst, Mellisa Lund, Brittany 
Dement, Elise Dufour, Olivier Tombret, Melina Calmon, Davette Gadison, and Khrystynep Tschinkel

2019 A Mass Sacrifice of Children and Camelids at the Huanchaquito-Las Llamas Site, Moche Valley, Peru. PLOS ONE 14(3):e0211691.

Rostworowski, Maria

1981 Recursos naturales renovables y pesca, siglos XVI y XVII. Instituto de Estudios Peruanos, Lima.

Samec, Celeste T., Hugo D. Yacobaccio, and Héctor O. Panarello

2018 Stable Isotope Compositions of South American Camelids in the Dry Puna of Argentina: A Frame of Reference for the Study of Prehistoric Herding and Hunting Strategies. Journal of Archaeological Science: Reports 18:628-636.

Sánchez Reyes, Cristian

2004 Crianza y producción de alpacas: Herencia ancestral. Ripalme, Lima.

Santana-Sagredo, Francisca, Elise Dufour, Nicolas Goepfert, Antoine Zazzo, Reguló Franco Jordán, and Segundo Vásquez Sánchez

2020 New Bioarchaeological Evidence and Radiocarbon Dates from the Lambayeque/Sicán Culture Camelids from the El Brujo Complex (Northern Coast of Peru): Implications for Funerary and Herd Management Practices. Environmental Archaeology 25:333-352.

Schoeninger, Margaret J., and Michael J. DeNiro

1984 Nitrogen and Carbon Isotopic Composition of Bone Collagen from Marine and Terrestrial Animals. Geochimica et Cosmochimica Acta 48:625-639.

Shimada, Melody, and Izumi Shimada

1985 Prehistoric Llama Breeding and Herding on the North Coast of Peru. American Antiquity 50:3- 26.

Squier, E. George

1877 Incidents of Travel and Exploration in the Land of the Incas. Harper Brothers, New York.

Sugiyama, Nawa, Andrew D. Somerville, and Margaret J. Schoeninger

2015 Stable Isotopes and Zooarchaeology at Teotihuacan, Mexico Reveal Earliest Evidence of Wild Carnivore Management in Mesoamerica. PLoS ONE 10(9):e0135635.

Szpak, Paul, Jean-François Millaire, Claude Chapdelaine, Christine D. White, and Fred J. Longstaffe

2020 An Integrated Isotopic Study of Early Intermediate Period Camelid Husbandry in the Santa Valley, Perú. Environmental Archaeology 25:279-295.

Szpak, Paul, Jean-François Millaire, Christine D. White, Steve Bourget, and Fred J. Longstaffe

2016 Life Histories of Sacrificed Camelids from Huancaco (Virú Valley). In Reconstructing Sacrifice on the North Coast of Peru: Archaeological Studies of Ritual Violence in the Ancient Andes, edited by Haagen D. Klaus and J. Marla Toyne, pp. 319-341. University of Texas Press, Austin.

Szpak, Paul, Jean-François Millaire, Christine D. White, and Fred J. Longstaffe

2014 Small-Scale Camelid Husbandry on the North Coast of Peru (Virú Valley): Insight from Stable Isotope Analysis. Journal of Anthropological Archaeology 36:110-129.

Tester, Richard F., Xin Qi, and John Karkalas

2006 Hydrolysis of Native Starches with Amylases. Animal Feed Science and Technology 130(1-2):39-54.
Therin, Michael, Richard Fullagar, and Robin Torrence

1999 Starch in Sediments: A New Approach to the Study of Subsistence and Land Use in Papua New Guinea. In Change in Subsistence Systems, edited by Chris Gosden and Jon Hather, pp. 438-462. Routledge, London.

Thornton, Erin Kennedy, Susan D. DeFrance, John Krigbaum, and Patrick R. Williams

2011 Isotopic Evidence for Middle Horizon to 16th Century Camelid Herding in the Osmore Valley, Peru. International Journal of Osteoarchaeology 21:544-567.

Tung, Tiffiny A., and Kelly J. Knudson

2010 Childhood Lost: Abductions, Sacrifice, and Trophy Heads of Children in the Wari Empire of the Ancient Andes. Latin American Antiquity 21:44-66.

Ugent, Donald, Shelia Pozorski, and Thomas Pozorski

1986 Archaeological Manioc (Manihot) from Coastal Peru. Economic Botany 40:78-102.

Vásquez, Víctor F., Luis Valle Alvárez, Teresa E. Rosales, Isabel Rey Fraile, and Gabriel Dorado

2018 Pruebas isotópicas, microscópicas y de artefactos de preparación y almacenamiento de chicha en Manchán (Casma, Perú). Arqueobios 12:4-17.

Verano, John

1995 Where Do They Rest? The Treatment of Human Offerings and Trophies in Ancient Peru. In Tombs for the Living: Andean Mortuary Practices, edited by Tom Dillehay, pp. 189-227. Dumbarton Oaks, Washington, DC.

2001 The Physical Evidence of Human Sacrifice in Ancient Peru. In Ritual Sacrifice in Ancient Peru, edited by Elizabeth Benson and Anita Cook, pp. 165-184. University of Texas Press, Austin.

Vinton, Sheila Dorsey, Linda Perry, Karl J. Reinhard, Calogero M. Santoro, and Isabel Teixeira-Santos

2009 Impact of Empire Expansion on Household Diet: The Inka in Northern Chile's Atacama Desert. PLoS ONE 4(11):e8069.

Wheeler, Jane C., A. J. F. Russel, and Hilary Redden

1995 Llamas and Alpacas: Pre-Conquest Breeds and PostConquest Hybrids. Journal of Archaeological Science 22:833-840.

Wilson, Andrew S., Emma L. Brown, Chiara Villa, Niels Lynnerup, Andrew Healey, Maria Constanza Ceruti, Johan Reinhard, Carlos H. Previgliano, Facundo Arias Araoz, Josefina Gonzalez Diez, and Timothy Taylor

2013 Archaeological, Radiological, and Biological Evidence Offer Insight into Inca Child Sacrifice. PNAS 110:13322-13327.

Yang, Xiaoyan, and Linda Perry

2013 Identification of Ancient Starch Grains from the Tribe Triticeae in the North China Plain. Journal of Archaeological Science 40:3170-3177.

Zazzo, Antoine, Marie Balasse, B. H. Passey, A. P. Moloney, F. J. Monahan, and O. Schmidt

2010 The Isotope Record of Short- and Long-Term Dietary Changes in Sheep Tooth Enamel: Implications for Quantitative Reconstruction of Paleodiets. Geochimica et Cosmochimica Acta 74:3571-3586.

Submitted January 31, 2020; Revised July 3, 2020; Accepted January 27, 2021 